\title{
Effect of Beetroot Juice on Anaemic Patients -an Analytical Study
}

\author{
Pushpaanjali. ${ }^{1}$, Brundha M. $P^{* 2}$, Leslie Rani. $S^{3}$ \\ Graduate Student, Department Of Pathology, Saveetha Dental College, Saveetha \\ Institute Of Medical And Technical Sciences, Chennai, Tamil Nadu, India \\ ${ }^{2}$ Associate Professor, Department Of Pathology, Saveetha Dental College, Saveetha \\ Institute Of Medical And Technical Sciences, Chennai, Tamil Nadu, India. \\ ${ }^{3}$ Tutor, Department of Pathology, Saveetha Dental College, Saveetha Institute of Medical \\ and Technical Sciences, 162, Poonamallee High Road, Chennai-600077, Tamil Nadu, India
}

\section{ABSTRACT}

Anaemia is a common name for a range of disorders that affect red blood cells. Red blood cells contain hemoglobin, which is responsible for carrying oxygen in the blood. To generate red blood cells, the body needs vitamin B12, iron and folic acid. If one or more of these factors are deficient, anaemia will develop. It is one of the most under-diagnosed conditions, if left untreated and can lead to many serious complications such as cardiovascular disease and compromised immune function. This aim of the study is to assess and evaluate the role of beetroot juice in increasing the Haemoglobin level and other Haematological parameters like MCV, MCH and MCHC. A group of 9 people with anaemia were selected for the study. Beetroot juice mixture was given to the group twice a day for 3 weeks. MCV, MCH, $\mathrm{Hb} \%$ are recorded before and after consumption by sending blood samples to the clinical lab of Saveetha Dental college. There was a significant raise in $\mathrm{Hb}$ level and slight improvement seen in MCV, MCH,and MCHC. It shows Beetroot juice can treat anaemia thereby increasing $\mathrm{Hb}$ level faster and more efficiently. Beetroot juice can be given as an alternative for Hematinics as they show immediate response of raising Haemoglobin level and other hematocrit parameters. Also they don't produce any side effects even if it is consumed for months.

KEY WORDS: ANEMIA, BEETROOT JUICE, PLATELETS, RED BLOOD CELL..

\section{INTRODUCTION}

Anaemia is characterized by lessening in the aggregate sum of hemoglobin or the quantity of red cells. Iron insufficiency pallor is a type of paleness because of the absence of adequate iron to form ordinary red cells

\section{ARTICLE INFORMATION}

*Corresponding Author: brundha.sdc@saveetha.com

Received 9th August 2020 Accepted after revision 24th Sep 2020

Print ISSN: 0974-6455 Online ISSN: 2321-4007 CODEN: BBRCBA

Thomson Reuters ISI Web of Science Clarivate Analytics USA and Crossref Indexed Journal

\section{Clarivate
Analytics}

NAAS Journal Score 2020 (4.31) SJIF: 2020 (7.728)

A Society of Science and Nature Publication,

Bhopal India 2020. All rights reserved.

Online Contents Available at: http//www.bbrc.in/

Doi: http://dx.doi.org/10.21786/bbrc/13.8/113
(Anderson, Frazer and McLaren, 2009). Iron insufficiency is the prevalent reason for weakness crosswise over nations. In both genders, ladies are commonly affected (McLean et al., 2009) (Kassebaum et al., 2014). Different components liable for pallor during pregnancy are gestational age, equality, continuous birth interim, history of overabundance seeping during period, intestinal parasitic contamination, jungle fever, interminable disease, and blood misfortune during pregnancy (Alemayehu et al., 2016) (Kaul et al., 2013).

Since the general iron prerequisite expands two-to three folds during puberty because of high development spurt and the loss of 12.5-15 mg iron every month, juvenile young ladies are helpless against paleness. Iron deficiency during youth is a nourishing issue and it has irreversible

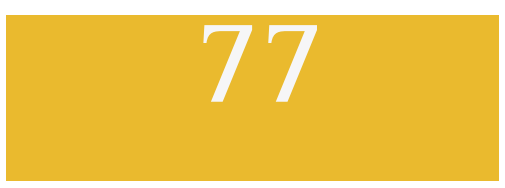


negative consequences for development of psychological growth and work execution (H. et al., 2018)(Bank and World Bank, 2003). Anaemia is a typical worry in geriatric age. In this populace, it can have fundamentally more serious complexities more than in the youthful grown-ups and can incredibly hamper the personal satisfaction (Lafuente et al., 2001).

The common beet plant of north america has it's tap root named as beetroot.It is one of a few developed assortments of Beta vulgaris developed for their palatable taproots and leaves (called beet greens); they belong to delegated B.vulgaris Subsp vulgaris Conditiva' Group (Okamura, Tokuzane and Dohi, 2013). According to Bakhru, creator of "Nourishments That Heal", said that beetroot juice is useful for treating sickness in youngsters and adolescents. Nirman Walker (2010) undertakes that beetroot assembles red corpuscles with betalain and adds tone to blood by enlarging the Hemoglobin levels. The charge of beetroot acquire is low in comparison with other iron-rich veg-tables (Rauha et al., 2000). Beetroot juice is used as a paleness solution for youngsters and adolescents, as per H.K.Bakhru, creator of food that heals".

\begin{tabular}{|c|c|c|c|c|c|c|c|c|}
\hline \multirow[b]{2}{*}{ Patients } & \multicolumn{4}{|c|}{ Before Consumption } & \multicolumn{4}{|c|}{ After consumption } \\
\hline & $\begin{array}{c}\mathrm{Hb} \\
\text { (g/dl) }\end{array}$ & $\begin{array}{c}\text { MCV } \\
\text { (fl) }\end{array}$ & $\begin{array}{c}\mathrm{MCH} \\
\text { (pg) }\end{array}$ & $\begin{array}{c}\text { MCHC } \\
(\mathrm{g} / \mathrm{dl})\end{array}$ & $\begin{array}{c}\mathrm{Hb} \\
(\mathrm{g} / \mathrm{dl})\end{array}$ & $\begin{array}{c}\text { MCV } \\
\text { (fl) }\end{array}$ & $\begin{array}{c}\mathrm{MCH} \\
\text { (pg) }\end{array}$ & $\begin{array}{c}\text { MCHC } \\
\text { (g/dl) }\end{array}$ \\
\hline 1 & 11 & 77.5 & 24 & 31 & 12.5 & 79 & 25.7 & 32.7 \\
\hline 2 & 11 & 88.5 & 29.5 & 32.2 & 12 & 90 & 30.4 & 33.7 \\
\hline 3 & 8.4 & 83 & 26 & 31 & 9.2 & 84 & 27.3 & 32.6 \\
\hline 4 & 11 & 83.5 & 25.2 & 32.5 & 13.4 & 85 & 26.7 & 33.6 \\
\hline 5 & 11.6 & 84 & 26 & 31 & 12.4 & 85 & 27.6 & 32.6 \\
\hline 6 & 9 & 87.5 & 27.2 & 31.2 & 10.5 & 89 & 28.9 & 32.4 \\
\hline 7 & 11 & 80.5 & 26 & 32.5 & 12.2 & 82 & 27.3 & 33.2 \\
\hline 8 & 8.2 & 89.5 & 28 & 31 & 9.3 & 91 & 29.6 & 32.4 \\
\hline 9 & 9.4 & 92 & 29.2 & 30.5 & 10.7 & 93 & 30.3 & 32.6 \\
\hline
\end{tabular}

Table 1a.

\begin{tabular}{|l|c|c|c|}
\hline & Mean & $\begin{array}{c}\text { Standard } \\
\text { Deviation }\end{array}$ & SEM \\
\hline Before & 10.178 & 1.433 & 0.478 \\
\hline After & 11.356 & 1.489 & 0.496 \\
\hline
\end{tabular}

Student's paired T test- $\mathrm{p}$ - valueP value is less than 0.0001

Table 2. Haemoglobin $(\mathrm{Hb})$ level in anaemic patients.

\begin{tabular}{|l|c|c|c|}
\hline & Mean & $\begin{array}{c}\text { Standard } \\
\text { Deviation }\end{array}$ & SEM \\
\hline Before & 85.111 & 86.444 & 1.543 \\
\hline After & 4.629 & 4.586 & 1.529 \\
\hline
\end{tabular}

Student's paired T test- $\mathrm{p}$ valueP value is less than 0.0001
Table 3. Mean Corpuscular Value (MCV) value in Anemia patients.

\begin{tabular}{|l|c|c|c|}
\hline & Mean & $\begin{array}{c}\text { Standard } \\
\text { Deviation }\end{array}$ & SEM \\
\hline Before & 26.789 & 1.836 & 0.612 \\
\hline After & 28.200 & 1.665 & 0.555 \\
\hline
\end{tabular}

Student's paired T test-p value $P$ value is less than 0.0001

Table 4. Mean Corpuscular Hemoglobin (MCH) in Anaemic patients.

\begin{tabular}{|l|c|c|c|}
\hline & Mean & $\begin{array}{c}\text { Standard } \\
\text { Deviation }\end{array}$ & SEM \\
\hline Before & 31.433 & 0.753 & 0.251 \\
\hline After & 32.867 & 0.502 & 0.167 \\
\hline
\end{tabular}

Student's paired T test- $\mathrm{p}$ valueP value is less than 0.0001 
Easton Patrick-says that expending beetroot juice or beet as cooked vegetable in a plate of mixed greens is exceptionally gainful in treating anemia. Beetroot contains a few profoundly bioactive phenolics, for example, rutin, epicatechin and caffeic corrosive which are likewise known to be phenomenal cancer prevention agents (Patel, Luke and Jeenath Justin Doss, 2017) The specialist saw that there is less spotlight on evaluation and the board of pallor among juvenile young ladies. Beetroot juice has positive effects on human blood and blood forming characteristics because of its higher iron substance. It recovers and reactivates the red cells. It supplies new oxygen to the body and helps the typical capacity of vesicular relaxing. In light of these the present examination was attempted by the analysts to concentrate on the requirements of the immature girls (Zielinnska-Przyjemska et al., 2009) The beetroot being a basic nourishment with $\mathrm{pH}$ from 7.5 to 8.0 has been acclaimed for its medical advantages, specifically for its sickness battling cell reinforcement potential.

Huge measure of nutrient $\mathrm{C}$ and nutrients $\mathrm{B} 1, \mathrm{~B} 2$, niacin, B6, B12 while the leaves are a brilliant wellspring of nutrients seen in beetroot (Dallman and Siimes, 1979). In iron insufficiency the convergence of hemoglobin is stopped by the confined stock of iron. This in turn have its effects on reduction in hemoglobin ( $\mathrm{Hb})$, mean corpuscular volume (MCV), mean corpuscular hemoglobin (MCH), and mean corpuscular hemoglobin Concentration(MCHC) (Neelwarne, 2012). This aim of the study is to assess and evaluate the role of beetroot juice in increasing the Haemoglobin level and other Haematological parameters like $\mathrm{MCV}, \mathrm{MCH}$ and MCHC.

\section{MATERIAL AND METHODS}

The mixture is prepared by extracting juice of beetroot of about $200 \mathrm{ml}$. $10 \mathrm{gm}$ of sugar is added to the mixture. The resulting juice mixture is given in the midday and evening (two times a day) for 3 weeks.

$\mathrm{MCV}, \mathrm{MCH}, \mathrm{Hb} \%$ are recorded before and after consumption by sending blood samples to the medical lab of Saveetha dental college.

Inclusion criteria: People with anemia of various age groups were included in this study.

Exclusion criteria: People with diabetes, allergic to Beetroot juice were excluded in this study. People with anaemia of inherited disorders and hemolytic anaemia are also excluded.

\section{RESULTS AND DISCUSSION}

Beet juice is considered to be a blood purifier, improves blood structure and cures diseases of the circulatory system, large intestine and digestive system. Drinking fresh beet juice may help in reversing anemia or other blood issues such as high cholesterol. The interventional study was conducted among 9 female anemia patients
(16) . Among them 5 female patients have mild anaemia and 4 female patients have moderate anaemia.

Table 1 shows the values of the patient's $\mathrm{Hb}, \mathrm{MCV}$, $\mathrm{MCH}$ and MCHC values before and after consumption of beetroot juice. The normal value of $\mathrm{Hb}$ in Males are $14-16 \mathrm{~g} / \mathrm{dl}$, Females $12-15 \mathrm{~g} / \mathrm{dl}$. The normal values of MCV are 81-97 fl, MCH are 28-53 pg, MCHC are 33-35 $\mathrm{g} / \mathrm{dl}$. From Table 2,3,4 and 5, it is seen that there was a significant raise in $\mathrm{Hb}$ level and slight improvement or changes seen in MCV, MCH and MCHC as the p value is less than 0.001. It shows Beetroot juice can treat anaemia by increasing the $\mathrm{Hb}$ level faster and more efficiently. This result supports the study conducted by Videl et al to compare the effectiveness of uncooked beetroot"s iron content with the synthetic iron content absorption. Vitamin C helps in rapid absorption of iron. As beetroot contains vitamin $\mathrm{C}$ as a natural substance, it helps in faster absorption. As Beetroot are rich in iron and Vitamin B12, it can be given as a supplement in treating Iron deficiency and Pernicious or Megaloblastic anaemia. As prevention is better than cure, we can advise the anemia patients to have beetroot juice regularly to reduce the complications of anemia. This study is a pilot study as the sample size is small (9 participants), further research has to be carried out about the role of beetroot in increasing the red blood cell count.

\section{CONCLUSION}

Within the limitations of the study, we conclude that Beetroot juice can treat anaemia by increasing the $\mathrm{Hb}$ level faster and more efficiently. Beetroot appears to be a powerful dietary source for several pathological disorders. Beetroot is one of the best ways to increase Hemoglobin levels. It is not only high in iron content but also contains folic acid, potassium and fiber. Therefore it is better to drink beetroot juice daily to ensure healthy blood count instead of undergoing long term hematinic therapy.

\section{ACKNOWLEDGMENTS}

We thank saveetha dental college for the support to conduct the study.

Conflict of intreast: There is no conflict of interest.

\section{REFERENCES}

Alemayehu, A. et al. (2016) 'Prevalence, Severity, and Determinant Factors of Anemia among Pregnant Women in South Sudanese Refugees, Pugnido, Western Ethiopia', Anemia, 2016, p. 9817358.

Anderson, G. J., Frazer, D. M. and McLaren, G. D. (2009) 'Iron absorption and metabolism', Current Opinion in Gastroenterology, pp. 129-135. doi: 10.1097/ mog.0b013e32831ef1f7.

Bank, W. and World Bank (2003) 'Health and Nutrition Services', World Development Report 2004, pp. 133156. doi: 10.1596/082135468x_chapter8.

Dallman, P. R. and Siimes, M. A. (1979) 'Percentile 
curves for hemoglobin and red cell volume in infancy and childhood', The Journal of pediatrics, 94(1), pp. 26-31.

H., M. K. G. et al. (2018) 'EVALUATION OF WEEKLY IRON AND FOLIC ACID SUPPLEMENTATION PROGRAM FOR ADOLESCENTS IN RURAL KANCHIPURAM, INDIA', National Journal of Research in Community Medicine, p. 101. doi: 10.26727/njrcm.2018.7.2.101-103.

Kassebaum, N. J. et al. (2014) 'A systematic analysis of global anemia burden from 1990 to 2010', Blood, 123(5), pp. 615-624.

Kaul, R. et al. (2013) 'Anemia in pregnant women in a rural block of Kashmir valley: Its prevalence and socio-demographic associates', International Journal of Medical Science and Public Health, p. 814. doi: 10.5455/ ijmsph.2013.130620131.

Lafuente, B. J. A. et al. (2001) 'Anemia e incapacidad funcional al ingreso en una residencia geriátrica', Anales de Medicina Interna. doi: 10.4321/s021271992001000100003.

McLean, E. et al. (2009) 'Worldwide prevalence of anaemia, WHO Vitamin and Mineral Nutrition Information System, 1993-2005', Public Health Nutrition, p. 444. doi: 10.1017/s1368980008002401.
Neelwarne, B. (2012) Red Beet Biotechnology: Food and Pharmaceutical Applications. Springer Science \& Business Media.

Okamura, H., Tokuzane, M. and Dohi, T. (2013) 'Quantitative Security Evaluation for Software System from Vulnerability Database', Journal of Software Engineering and Applications, pp. 15-23. doi: 10.4236/ jsea.2013.64a003.

Patel, R., Luke, F. and Jeenath Justin Doss, K. (2017) 'A Study to Assess the Effectiveness of Beetroot Juice with Jaggery on Anemia among Adolescent Girls in the Selected Urban Area at Rajkot', International Journal of Nursing Education and Research, p. 140. doi: 10.5958/2454-2660.2017.00029.1.

Rauha, J.-P. et al. (2000) 'Antimicrobial effects of Finnish plant extracts containing flavonoids and other phenolic compounds', International Journal of Food Microbiology, pp. 3-12. doi: 10.1016/s01681605(00)00218-x.

Zielinnska-Przyjemska, M. et al. (2009) 'In vitroeffects of beetroot juice and chips on oxidative metabolism and apoptosis in neutrophils from obese individuals', Phytotherapy Research, pp. 49-55. doi: 10.1002/ ptr.2535. 